of the reservations of the Governments asked to commit themselves to these oil policies. An oil policy for Europe fitting the provisions of the Treaty of Rome and a coal policy fitting a possibly revised Treaty of Paris could exist, but he hesitates to suggest that this will be the outcome. What is remarkable, moreover, is the almost complete absence in the Broadsheet of any reference to nuclear energy.

\title{
PETROLEUM IN 1975
}

$\mathrm{O}$ N April 27, 1963, Esso Petroloum Co., Ltd., celebrated its seventy-fifth anniversary and a special issue of the Esso Magazine was published to mark this milestone in the Company's history.

The leading article, entitled "A Look Ahead to 1975", makes some interesting forecasts for the petroleum industry in Britain. If world economic progress during the next twelve years continues at the same rate as in the past twelve years, it is estimated that world oil demand will rise from the 1962 figure of 1,200 million tons to 2,200 million tons in 1975; in Britain the demand will approximately double the 1962 figure of 52 million tons to 102 million tons by 1975. New sources of oil may stem from the discovery of large natural gas deposits in Holland in 1961 and this has inspired an under-water search for oil off the British coast in the North Sea, a joint venture by Esso, Shell and British Petroleum. Esso is at present exploring possibilities in Kent, Sussex and Hampshire.

In the matter of transporting crude oil from overseas to refineries in Britain, tankers of 26,000 tons d.w. were among the largest afloat in the 1950's; now 80,000-ton tankers are already a feature of the Esso fleet and an 86,000 -ton ship is scheduled for service early next year. The economic advantages of tankers up to 150,000 tons d.w. are at present under consideration, and the possibility of nuclear-powered tankers being used by 1975 is by no means remote.
If the forecast of demand for petroleum products doubling itself in the next twelve years is correct, then Britain's refining capacity will have to be increased to take care of at least another 50 million tons of oil by 1975 , involving a capital outlay in the region of $£ 200$ million. In the distribution of refined products, pipe-lines are destined to play an increasingly important part in the years ahead; it is estimated that by 1975 about two. thirds of the 'white' products marketed by Esso alone in south-east England and the Midlands will travel by pipe-lines.

Fuels for engines of all kinds, ships' bunkers, cars, lorries, locomotives, aviation fuels, etc., are expected to increase the demand by 75 per cent, oils for heating about 70 per cent greater in 1975 than in 1962 . Regarding heavy oils for industry, apart from traditional fuels, now methods of generating electricity are anticipated by 1975 , such as magnetohydrodynamics, which converts the energy into hot gases, produced by burning fuel, directly into electricity in a strong magnetic field; the fuel cell would convert petroleum products into energy at a much higher efficiency than 45 per cent, the maximum efficiency that at present is achieved in the modern power station. Finally, the capital expenditure in Britain to cover all these developments in the oil industry is anticipated to be more than $£ 1,000$ million during the next twelve years.

H. B. MILNER

\section{PRE-FLUVIAL, AUTOGEOSYNCLINAL SEDIMENTATION IN THE NAMURIAN OF THE SOUTHERN CENTRAL PROVINCE}

By B. K. HOLDSWORTH

Department of Geology, University of Keele

$S^{\mathrm{I}}$ INCE the publication of Gilligan's ${ }^{1}$ now classic study, British stratigraphers have stressed the deltaic and terrestrial aspect of Namurian rocks developed in the Central Province of England-'The Millstone Grit Series'.

While coarse, cross-bedded arkosic sandstones-the 'fluvial grit facies' of Trotter ${ }^{2}$ - such as those investigated by Gilligan undoubtedly record terrestrial, fluvial activity (cf. ref. 3) and represent an important stage in the evolution of the Central Province, it has long been realized that in the south of the Province a complex history of Upper Carboniferous sedimentation preceded the first appearance of fluvial conditions ${ }^{4-6}$. An important newly published account of Carboniferous rocks in the Ashover district ${ }^{7}$ together with earlier work in the StaffordshireDerbyshire region and recent investigations in north Staffordshire and south-west Derbyshire allows the period between the close of the Dinantian and the first establishment of fluvial environments in the region to be seen in clearer perspective.

Hudson and Cotton ${ }^{8}$ stressed that Dinantian successions in the area are of two contrasting aspects-'basin' and 'massif'. The sedimentation contrast was apparently related to a northerly projection of the Carboniferous Central Land Barrier (St. George's Land). On the submerged surface of this projection from the ancient block developed the limestones of 'massif facies'. To the north and west lay the basin area.

During $D 1(B 2)$ time a part of the western and northern margin of the block projection in Derbyshire became marked by a line of limestone-reef building activity. To-day the belt of 'reef-knolls' is almost completely exposed from the upper Dove Valley to the Castleton district. East and south of the belt in Derbyshire, backreef, massif limestones are exposed (cf. refs. 9 and 10). West and north of the belt, in north Staffordshire and north Derbyshire respectively, borings show contemporaneous limestones and shales of basin aspect ${ }^{8}$.

A slight increase in differential movement between the geotropically negative basin- and positive massif-areas probably explains the $D 1(B 2)$ reef-building episode and it appears that this movement continued into $D 2$ times. By late $P$ time, however, the positive tendency of the massif projection appears to have been lost and rather similar, relatively argillaceous limestones accumulated over earlier basin- and earlier massif-areas alike ${ }^{8}$.

The framework which was to govern tho distribution of sediment accumulation during some two-thirds of Namurian time now developed, probably in late $P$ time, through recrudescence of differential movement between basin- and massif-regions. Uplift along the earlier reefbuilding line resulted in an essentially monoclinal fold. Erosion exposed the line of $D I(B 2)$ knolls and gave rise to the local $D 1(B 2)-E 2$ (Namurian) unconformity at the massif margin in north Derbyshire ${ }^{11}$ and the upper Dove Valley $^{8}$.

The re-establishment of a positive tendency in the massif exerted a profound control on Namurian sediment accumulation. Contrast between thick earlier Namurian 